DOI: $10.25178 /$ nit.2019.1.8

\title{
Фольклор старообрядцев таежных деревень Верховья Енисея в репертуаре детского ансамбля «Октай»"
}

\author{
Маргарита П. Татаринцева \\ Тувинский институт гуманитарных и прикладных социально-экономических исследований, \\ Российская Федерация
}

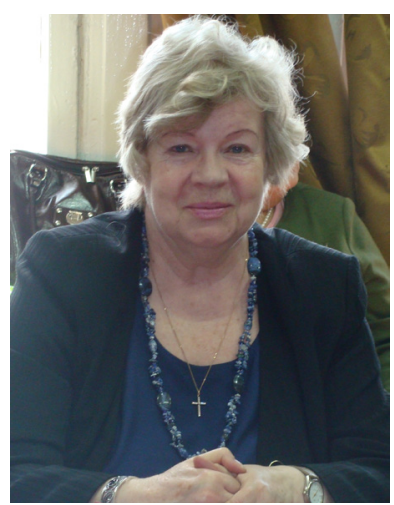

В статье рассматривается та часть репертуара детского фольклорно-этнографического ансамбля «Октай» (Тува), которая воссоздает фольклор старообрядиев Верховья Енисея, в частности духовную музыку. Автор опирается на материалы своего общения с руководителем ансамбля, на личные наблюдения, на публикации об ансамбле.

Духовные песнопения и духовные стихи у массового слушателя - не самый популярный жанр, для их восприятия требуется особый настрой, особая подготовка. Тем не менее этот жанр постоянно присутствует в репертуаре ансамбля. Это одна из задач коллектива - освоение подлинной русской народной певческой культуры и местных фольклорных традиций, в частности.

С начала существования фольклорного ансамбля коллектив выезжает каждое лето в таежные деревни верховья Малого Енисея на отдых, оздоровление, для знакомства с бытом старообрядиев и для записи фольклора. На сегодня репертуар «Октая» включает около 200 духовных стихов, значительная часть записана у местных старообрядиев самими октаевцами, а также фольклористами Г. О. Туденовым, С. Е. Никитиной и автором этой cтатьи.

Стало хорошей традицией выступления детей с концертами перед староверами Эржея и Сизима. Это влияет на молодежь староверческих деревень. У девушек стали появляться современные стихарники тетради или альбомы с записями стихов.

В целом, опыт ансамбля «Октай», его деятельность по возрождению угасающей традиции пения духовных стихов в среде верхнеенисейских староверов представляет для фольклористов и культурологов большой интерес.

Ключевые слова: Тува; Енисей; старообрядцы; русский фольклор; духовные стихи; фольклорный ансамбль; Октай

"Подготовлено при поддержке РФФИ (проект «"Енисейский меридиан" старообрядчества: сохранение и развитие традиции в условиях таежных скитов и деревень», грант № 18-09-00723).

\section{Для цитирования:}

Татаринцева М. П. Фольклор старообрядцев таежных деревень Верховья Енисея в репертуаре детского ансамбля "Октай" [Электронный ресурс] // Новые исследования Тувы. 2019, № 1. URL: https:// nit.tuva.asia/nit/article/view/832 (дата обращения: дд.мм.гг.). DOI: 10.25178/nit.2019.1.8

Татаринцева Маргарита Петровна - кандидат филологических, ведущий научный сотрудник сектора культуры Тувинского института гуманитарных и прикладных социально-экономических исследований. Адрес: 667000, Россия, г. Кызыл, ул. Кочетова, д. 4. Тел.: +7 (394-22) 2-39-36. Эл. адрес: margotatar@mail.ru ORCID:0000-0002-2118-1926

Tatarintseva Margarita Petrovna, Candidate of History, Principal research fellow, Sector of culture, Tuva Institute for the Humanities and Applied Socioeconomic Studies. Postal address: 4 Kochetov St., 667000 Kyzyl, Russian Federation. Tel.: +7 (394-22) 2-39-36. Email: margotatar@mai.ru 


\title{
The folklore of the Old Believers from the taiga villages of the Upper Yenisei in the repertoire of children's ensemble Oktai"
}

\author{
Margarita P. Tatarintseva \\ Tuvan Institute for the humanities and applied socio-economic studies, \\ Russian Federation
}

The article explores a part of the repertoire of children's folklore and ethnographic ensemble "Oktai" (Tuva), which recreates the folklore of the Old Believers of the upper Yenisei, in particular their spiritual music. The article is based on the communications the author had with the leader of the ensemble, as well as on personal observations and existing publications about the ensemble.

Spiritual chants and spiritual poems are not the most popular genre among the mass audience, since their perception requires a particular attitude and special preparation. Nevertheless, this genre is constantly present in the repertoire of the ensemble. One of the aims of the collective is to master both genuine Russian folk singing culture, in general, and specific local folklore traditions.

From its very start, the ensemble has been coming to the taiga villages of the upper Small Yenisei every summer for rest and recovery, as well as to experience the life of the Old Believers and record their folklore. Today the repertoire of "Oktay" includes about 200 spiritual verses, a lot of them are recorded from local Old Believers by members of "Oktai", folklorists G. O. Tudenov, S. E. Nikitina, and the author of this article.

It has become a good tradition for the children to give summer performances for the Old Believers of villages Erzhey and Sizim. Under the impact of these concerts, Old Believer girls started to make up modern versions of the stikharniki - notebooks or albums filled with poems.

On the whole, the experience of the "Oktai" ensemble, its activity to give new life to the fading tradition of singing spiritual verses among the Old Believers of the upper Yenisei is of great interest to both folklorists and scholars of culture.

Keywords: Tuva; Yenisei; Old Believers; Russian folklore; spiritual verses; folklore ensemble; Oktai

"Supported by RFBR, project no18-09-00723 "The Yenisei Meridian" of the old believers: the preservation and development of traditions in taiga monasteries and villages.

\section{For citation:}

Tatarintseva M. P. The folklore of the Old Believers from the taiga villages of the Upper Yenisei in the repertoire of children's ensemble Oktai. The New Research of Tuva, 2019, no. 1 [on-line] Available at: https:// nit.tuva.asia/nit/article/view/832 (accessed: ... ). DOI: 10.25178/nit.2019.1.8

\section{Введение}

Детский фольклорно-этнографический ансамбль «Октай» (Тува) существует уже почти тридцать лет (создан в 1990 г.). Он хорошо известен в республике и за ее пределами, участвовал во множестве конкурсов, смотров и фестивалей, неоднократно выступал за границей. Рождение ансамбля оказалось связанным с той волной «фольклорного ренессанса», движения, которое охватило Россию и СССР, начиная с 1960-1970-х годов и продолжилось позже. Ревнители подлинно народного, аутентичного исполнения фольклора стали создавать фольклорные и фольклорно-этнографические ансамбли, которые зачастую сочетали исполнительскую деятельность с собиранием и изучением фольклора на местах, с тем, чтобы творчество сделать идентичным его образцам, которые можно найти у исполнителей - жителей деревень российской глубинки, где традиционный стиль исполнительства еще сохранялся. Фольклорные произведения всегда существовали в этнографическом контексте и в современных условиях этот контекст нужно было воссоздать. Во вновь создаваемых ансамблях наблюдался интерес к духовной музыке, в частности, в их репертуар стали входить и духовные стихи, жанр, уже редко встречавшийся в живом бытовании, но, тем не менее, не исчезнувший совсем. 
Продемонстрируем это на примере ансамбля «Октай», каждое выступление которого включает самые разнообразные жанры певческого фольклора русского народа - от полузабытых духовных стихов до протяжных и веселых задорных песен - игровых и плясовых - с дудками, трещотками, пищалками, жужжалками, свистульками... При этом этнографическая идентичность группы подчеркивается традиционными костюмами юных артистов, характерной народной пластикой движений, включением народных игр в массовые празднества, в том числе и хоровод, общим влиянием их выступлений - талантливых, увлеченных, задорных на слушателей, в том числе на подрастающее поколение.

В настоящей статье я не имею возможности охарактеризовать весь разнообразный репертуар детского ансамбля, а подробнее остановлюсь на духовной музыке, а больше всего на духовных стихах, еще бытующих в среде староверов Верховья Енисея, но встречающихся все реже. Об этой стороне исполнительского мастерства «Октая» имеются отдельные высказывания и суждения компетентных профессионалов, фольклористов и музыковедов, которые я постараюсь воспроизвести, а также отзывы обычных слушателей - любителей и ценителей этого жанра. Основная часть фактов о конкретных событиях тридцатилетней истории «Октая», формировании его репертуара излагались руководителем ансамбля в личных беседах со мной, автором этой статьи, в телефонных разговорах и электронной переписке. Конечно, активно использовался метод личного наблюдения.

Существует довольно обширная газетно-журнальная библиография о творчестве и концертной деятельности ансамбля, и некоторые отклики приведены в этой статье, в целом же газетные выступления не носят аналитического характера, они, в основном, информационны и хвалебны. И в подаче материала, и манере изложения они мало чем отличаются друг от друга, хотя за тридцать лет их накопилось столько, что можно было бы составить отдельную книгу.

Духовные песнопения и духовные стихи у массового слушателя - не самый популярный жанр, для их восприятия требуется особый настрой, особая подготовка, некоторые знания библейских и евангельских историй, что не представляет особой сложности в староверческой аудитории, даже детской, поскольку их семейное воспитание в основном знакомит детей с религиозной литературой, библейскими сюжетами и притчами, но такое восприятие не всегда достижимо в рамках обычного концерта для массовой публики. Тем не менее этот жанр постоянно присутствует в репертуаре детского ансамбля, в этом отношении его руководитель Н. В. Пономарева с самого начала занимает четкую принципиальную позицию.

Духовные стихи в таежных деревнях Малого Енисея в 1970-1990 годы записывали фольклористы Г. О. Туденов, С. Е. Никитина, автор этой статьи и сама Н. В. Пономарева с детьми из ансамбля. Эти записи хранятся либо в Научном архиве Тувинского института гуманитарных и прикладных социально-экономических исследований (ТИГПИ), либо в личных архивах собирателей, которые, кстати, охотно делятся своими записями с «Октаем» (например, С. Е. Никитина и автор этих строк).

К духовной музыке, в том числе и богослужебной, а также духовным стихам «Октай» всегда испытывал большой интерес. Духовная музыка обычно исполнялась во время религиозных церковных праздников, служб, в которых самое непосредственное участие принимали рядовые верующие. А духовные стихи, отвечая мировоззренческим взглядам старообрядцев, были всегда известны и востребованы в их среде. Музыковед Е. К. Карелина пишет: «”Октай” выделяется среди других фольклорных коллективов своеобразной “старообрядческой” манерой исполнения, очень органичной, напрочь лишенной театральности» (Карелина, 2009: 104).

В качестве показательного примера успешного освоения этого жанра достаточно напомнить, что высокопрофессиональное исполнение в конкурсной программе фестиваля «Вече малых городов России» в Царском Селе (Санкт-Петербург, 1995 г.) выгодно выделило «Октай» среди других исполнителей. Тогда ансамбль из Тувы в количестве всего восьми детей поразил членов жюри, состоявшего из ведущих фольклористов Москвы и Санкт-Петербурга, не только подбором материала, но и высоким певческим мастерством. 


\section{НОВЫЕ ИССЛЕДОВАНИЯ ТУВЫ}

Www.nit.tuva.asia
№1

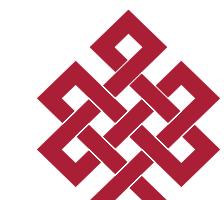

THE NEW RESEARCH OF TUVA

Novye issledovaniia Tuvy

После выступления ансамбля в Москве на конференции «Русская церковная музыка Средневековья» в 1995 г. дирекция центрального музея древнерусской культуры и искусства имени Андрея Рублева вручила ансамблю благодарственную грамоту, в которой говорится: «Дирекция благодарит ансамбль “Октай” под руководством Н. В. Пономаревой за прекрасное выступление на открытии конференции Русская церковная музыка Средневековья», а также на открытии выставки “Крит. Восточное Средиземноморье и Россия в XVII в.”. Ансамбль своим творчеством вносит неоценимый вклад в изучение традиций старообрядцев верхнего Енисея и в целом в изучение народной культуры». Документ подписан директором музея Г. В. Поповым.

Особую манеру пения «Октая» с элементами архаики выделил и петербургский «Коммерсантъ» в 1996 г. во время выступления ансамбля на конференции «Церковно-певческая культура православного мира». В статье говорилось: «После мужских хоров (вспомним, что женщины были допущены на клирос лишь в конце XIX века) на сцене появился Детский фольклорный старообрядческий хор “Октай” из Кызыла. Тропарь “Христос воскресе” был исполнен в народной манере (подлинные костюмы, открытый звук, неканонический текст) с оттенком фанатической убежденности, и так было воссоздано сохраненное лишь старообрядцами церковное пение» (Православный ..., 1996: Электр. ресурс).

Газетные отклики, освещавшие конкурсы духовной музыки, проходившие в Москве и Санкт-Петербурге, в которых наряду со взрослыми коллективами исполнителей, а порой и профессионалами, принимал участие и «Октай», единодушно отмечали высокие достоинства исполнения столь сложных произведений юными певцами, которые были удостоены почетных наград.

Надо сказать, что после выступлений в Новосибирске, Москве и Санкт-Петербурге «Октай» получил предложения сделать записи духовной музыки верхнеенисейских старообрядцев на аудиокассеты и диски ${ }^{1}$.

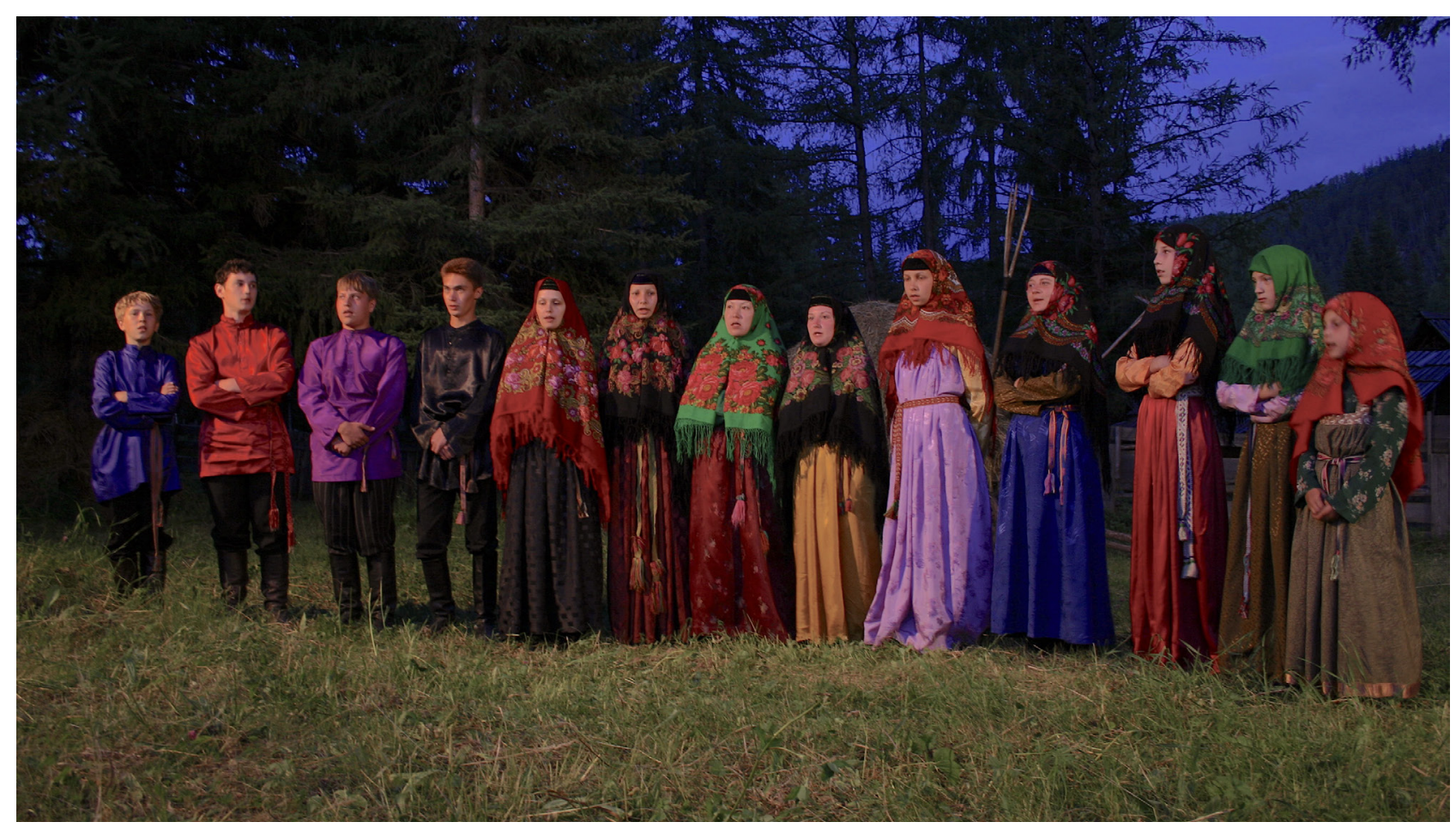

Фото 1. Выступление на таежной поляне. Фото из архива Н. В. Пономаревой. Photo 1. A concert on a glade in the taiga. Photo from N.V. Ponomaryova's archive.

${ }^{1}$ На сегодня у ансамбля записаны два диска и одна аудиокассета. 


\section{Фольклор староверов Верховьев Енисея}

Одной из своих задач ансамбль ставил освоение подлинной русской народной певческой культуры вообще и местных фольклорных традиций, в частности. Ранее мне уже приходилось писать о русском фольклоре в Туве и фольклоре местных старообрядцев, о духовных стихах (Татаринцева, 1993, 2006, 2017). приведу некоторые собственные наблюдения и выводы, касающиеся этой темы.

В Туве наибольшая сохранность традиций и русской народной культуры в целом, духовной и бытовой, наблюдается в среде староверов, компактно проживающих в таежных поселениях верховья Каа-Хема-Малого Енисея (далее - Верховье): в деревнях Сизим, Эржей, Ужеп, Бельбей и в других совсем уже небольших населенных пунктах. В течение века в таежной глуши Верховья действовали скиты-монастыри, насельники которых в непрерывных молитвах, трудах и монашеской аскезе видели средство спасения души. Скиты оказывали сильное консолидирующее влияние на жителей окрестных деревень по сохранению крепости старой веры и связанных с нею строгих традиций. Современные исследователи старообрядчества считают старообрядцев Верховья «ортодоксальными» (Костров, Пригарин, 2018: 45), так как в их среде лучше, чем в других местах расселения старообрядцев нашей страны сохранились патриархальные устои жизни в семье, быту, строго соблюдаются многочисленные религиозные запреты и ограничения, связанные со стремлением сохранить «свой» мир и не поддаваться искушениям мира «еретиков»- падшего, «чужого», от которого они когда-то решили удалиться, выбрав для жительства эти удаленные и труднодоступные места.

Русское крестьянское население появилось в Туве немногим более века, в основном это были выходцы из соседних с Урянхаем (тогда так называлась Тува) сибирских губерний и Алтая, которые когда-то переселились в Сибирь из Европейской России. В Туву их манили природные богатства края и обилие пригодных для землепашества свободных земель. Примерно третью часть переселенцев составляли старообрядцы, которых, кроме уже названных причин для переселения, привлекала возможность свободно исповедовать старую веру, за которую в России они подвергались гонениям со стороны государства и официальной церкви.

В целом русские переселенцы, по происхождению имеющие корни в разных областях Сибири и Европейской России, на территории Тувы оказались носителями разных культурных и фольклорных традиций, поэтому в одной большой деревне можно было наблюдать мозаичную фольклорную картину - услышать и старинные русские, и сибирские, и украинские песни. Единые песенные традиции за такой короткий исторический срок сформироваться в русских деревнях Тувы просто не успели.

Старообрядцы часовенного согласия, с течением времени компактно поселившиеся в верховье Малого Енисея, представляют собой закрытое для посторонних религиозное сообщество. Их сакральная и обыденная жизнь отличается многими запретами и ограничениями. Фольклор здесь также имеет свою специфику: большинство праздничных развлекательных и увеселительных его жанров считаются греховными, потому что для строго исполняющих все предписания устава староверов праздник - это время молитв и отдыха. А обычные мирские песни, частушки бытуют в «усеченном» виде, т. е. звучат редко. Не держат староверы в доме и музыкальных инструментов. «Старообрядческий Бог боится шума», - с иронией когда-то писал П. Маслов, посетивший край с целью переписи населения в конце 20-х годов XX века (Маслов, 1933: 129).

Но духовные стихи разрешалось петь даже во время поста. Правда, в более ранние времена, когда в местных монастырях было немало молодых скитниц, по воспоминаниям, строгий наставник накладывал епитимью на инокинь за то, что смотрелись в зеркало, пели духовные стихи в пост...

По воспоминаниям людей старшего поколения, раньше также старообрядцы детей учили читать по церковным книгам на старославянском языке, а вместо колыбельных песен мла- 


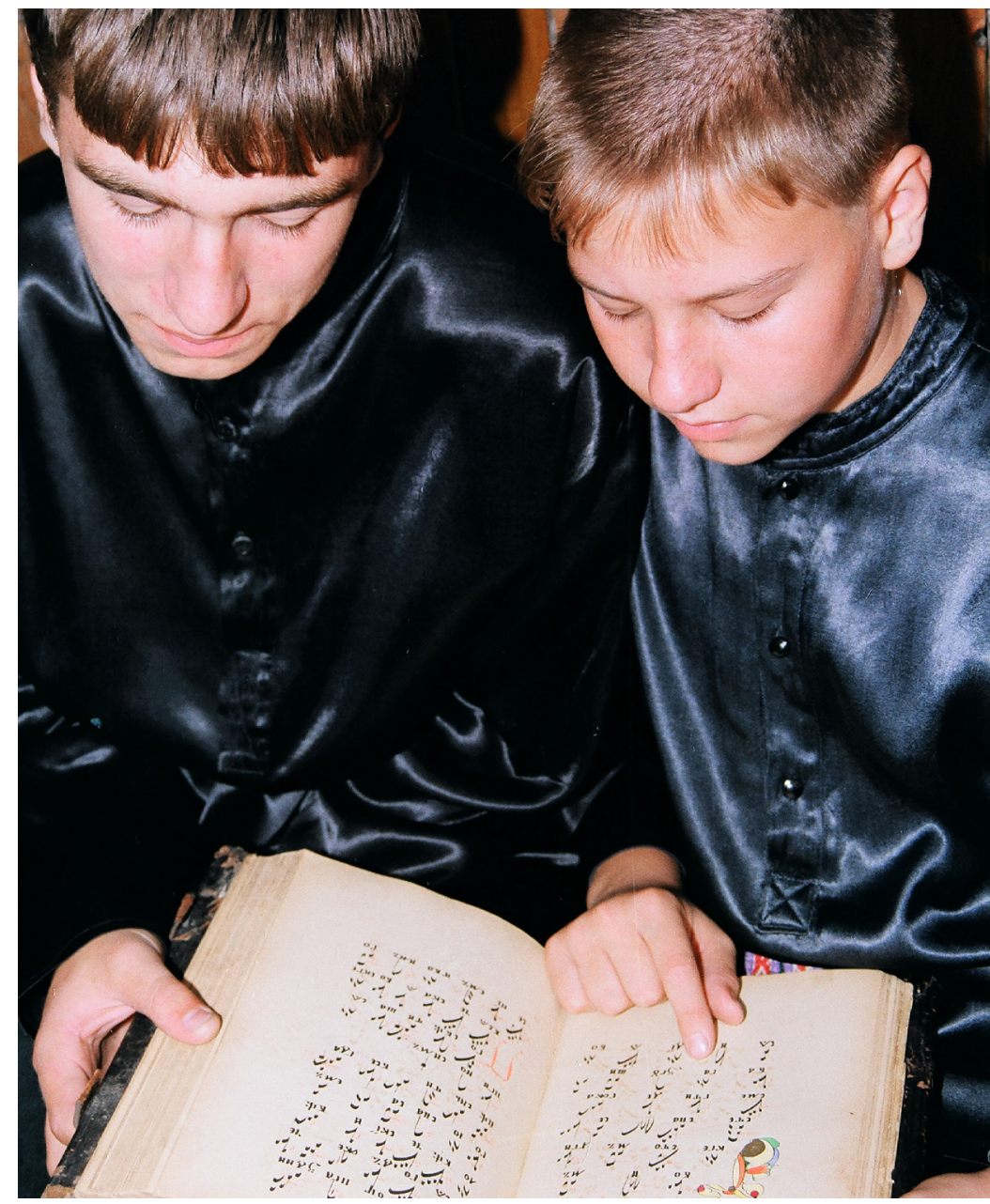

Фото 2. Читаем «Октай». Фото из архива Н. В. Пономаревой. Photo 2. Reading the Oktai. Photo from N.V. Ponomaryova's archive. денцу пели духовные стихи. Онито и сохранились лучше, чем у кого-либо, именно в среде старообрядцев как более востребованные, отвечающие их духовным запросам и дающие возможность выразить свое отношение ко всему происходящему в мире. Это органическая часть их духовной культуры. Стилистически, жанрово духовные стихи неоднородны и довольно разнообразны, широк и тематический спектр этих произведений - эсхатологические (о близком конце света), библейские, исторические, о подвижниках веры, лироэпические, лирические, покаянные... Герой лирических, покаянных духовных стихов - человек глубоко верующий, страдающий, осознающий неправедность суетного мира и собственную греховность, озабоченный спасением души, которой после смерти суждено предстать перед Страшным судом.

Мелодию духовного стиха исполнители воспроизводят по памяти, а текст могут читать по записи - многие стихи очень длинные, хотя самые популяр-

ные стихи поются наизусть, подобно обычным народным песням.

Морально-ценностные приоритеты воспитанных на религиозной литературе старообрядцев соответствуют идеям, заложенным в духовных стихах - это забота о спасении души, кратковременность земной жизни и взгляд на нее как на подготовительный этап к жизни вечной, идеи нравственной ответственности человека перед Богом за земную жизнь и др. В целом для текстов духовных стихов характерен «фольклорный примитивизм», безыскусность и искренность. Конечно, на содержание духовных стихов повлияла религиозная литература, имеющая широкое распространение в среде староверов, а на манеру исполнения - церковные песнопения. Поэтому фольклористы определяют двойственную природу жанра духовных стихов как устно-письменную.

Обращает на себя внимание то, как староверы, исполняя или слушая духовные стихи, актуализируют и личностно воспринимают их тематику, непосредственно соотносят их содержание с событиями и переживаниями сегодняшнего дня. Свойство культуры старообрядцев - соотносить проблемы текущего времени с Ветхим Заветом, другими авторитетными сочинениями для лучшего их понимания и правильного разрешения не раз отмечалось исследователями, например, Н. Покровским (Покровский, 1984: 16-17). В определенной степени это свойство - актуализация религиозного или фольклорно-притчевого текста - распространяется и на духовные стихи. В них старообрядцы как бы моделируют мир в соответствии 
со своим мировоззрением, это их способ переживания мира. Зачастую не ощущается даже той дистанционности, которая обычно бывает при исполнении традиционного фольклора: исполнители и слушатели воспринимают и библейских персонажей, и лирических героев как реально существующих людей. Тем и объясняется востребованность и лучшая сохранность этого жанра в этом социуме.

Духовные стихи «переводят религиозные идеи на язык народных представлений и эмоций», - считает известный исследователь этого жанра С. Е. Никитина, также записывавшая их в Туве (Никитина, 1994b: 33-34). Именно ей исполнители духовных стихов в деревнях верховья Малого Енисея говорили, что стихи нужно петь «важно и умильно» (Никитина, 1994а: 11).

С такими особенностями бытования фольклора столкнулись руководители и участники ансамбля, делая попытки записать и включить в свой репертуар местный фольклор старообрядцев.

\section{«Октай» и фольклор староверов Верховья}

Руководители ансамбля решили изучить старинную культуру местного населения, духовную и бытовую, собрать фольклор этих мест и по возможности активно использовать его в репертуаре ансамбля. Н. В. Пономарева, с которой мне много приходилось общаться в процессе написания этой статьи, считает так:

«Для того, чтобы называться фольклорным, да еще и этнографическим, коллектив должен работать с аутентичным фольклором, а так как мне вместе с детьми первого состава (с 1990-е гг. - М. Т.) посчастливилось застать в живых и записать последних исполнителей духовных стихов местной традиции, то сам Бог велел заниматься этим жанром».

Интересна и показательна история названия детского фольклорно-этнографического ансамбля. Как вспоминает Н. В. Пономарева, в одном доме старообрядцев участники ансамбля увидели старинную книгу религиозных песнопений в кожаном переплете с крюками вместо нот - ведь старообрядцы являются носителями традиций древнерусского певческого искусства - знаменного распева. Называлась она «Октай» - так именуется местными старо-

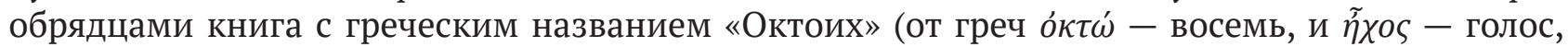
т. е. осьмогласник, восьмигласный). А так как с начала своего существования ансамбль был ориентирован на сбор фольклора местного русского населения, усвоение его манеры пения, название старинной певческой книги старообрядцев сочли символическим, благозвучным и подходящим для фольклорно-этнографического коллектива.

Н. В. Пономарева и педагоги строят свою работу так, чтобы для детей, которые приходят к ним с 6-7 лет, фольклорное пространство народной культуры расширялось постепенно по мере их роста. Занимаясь в ансамбле, дети учатся играть на народных инструментах, самостоятельно изготавливать традиционные русские игрушки, осваивают пляски и типичную народную пластику движений, получают представление о традиционном русском костюме и т. д. Во время летнего отдыха в Эржее они знакомятся с хозяйственно-бытовой жизнью детей староверов - учатся копать картошку, поить коней и др.

Даже обширный подвал - место постоянного обитания октаевцев - стилизован под крестьянскую горницу. Здесь стоят деревянные лавки, сундуки, самовар, прялка, расстелены самотканые дорожки. Прочее убранство помещения сильно отличается от современной городской квартиры.

Малыши в самом начале осваивают простейшие танцевальные движения, пластику народного жеста. Для развития дикции, свободной артикуляции голосового аппарата в работе с младшим составом педагогами активно используются игровые элементы. Например, скороговорки, развивающие правильное произношение звука «р», шипящих, свистящих согласных, скорость и чистоту произношения и т. д. Сначала медленно, а потом все быстрее дети про- 


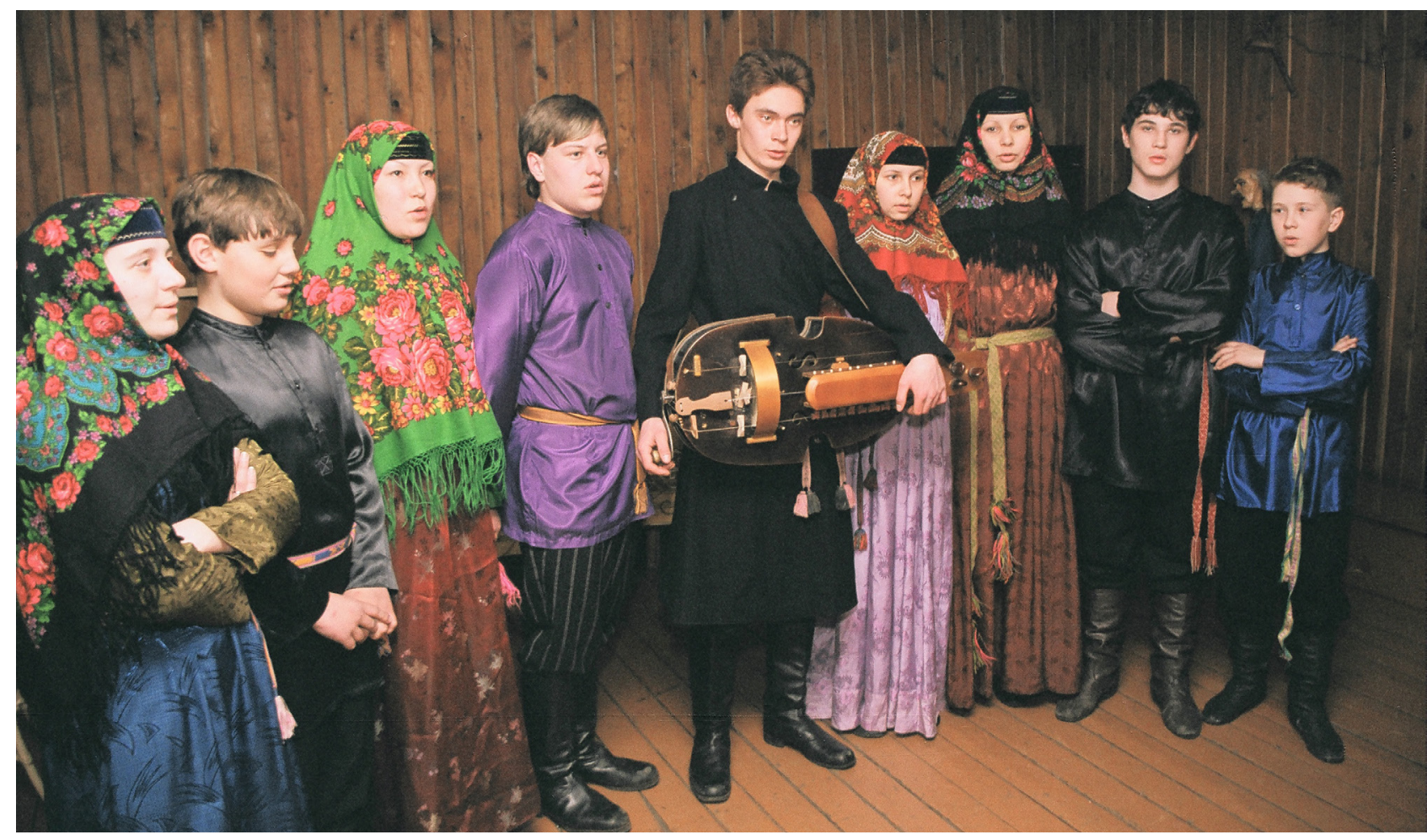

Фото 3. Духовные стихи исполняются «важно и умильно» в сопровождении колесной лиры. Фото из архива Н. В. Пономаревой. Photo 3. Spiritual verse is sung in a «solemn and touching» manner, accompanied by the sound of the wheel lyre. Photo from N. V. Ponomaryova's archive

говаривают их. Дети идут сюда совершенно добровольно, потому что занятия эти не только полезны, но и интересны.

С учетом возможностей для детей младшего возраста проводятся распевки, специальные упражнения для овладения народной манерой пения, умения подстраиваться «на слух». Заметим, что все музыкальное обучение в ансамбле идет не по нотам, а «на слух», т. е. основано на подражании манере умелых исполнителей, как это всегда было в народном быту. Вот как об этом пишет доктор искусствоведения, музыковед Е. К. Карелина: «Творческая деятельность “Октая" имеет свои специфические особенности, которые характерны именно для фольклора как культуры устной традиции. Вначале записывают или запоминают то, что поют бабушки. Потом раскладывают услышанное на несколько голосов по подсказке бабушек или по собственному наитию... Когда ребята из Кызыла запели разложенные Надеждой на голоса духовные стихи, бабушки приняли их: “По-нашему поете”» (Карелина, 2009: 104).

Для младшего состава подбирается и соответственный репертуар - игровые детские песенки, например, «Козел», «Гуси» «Тетеря» и др. Однако довольно часто старшая и младшая группа ансамбля выступают совместно и на сценических площадках, и на народных гуляниях, и во время торжественных народно-церковных праздниках с пением богослужебных произведений и духовных стихов. Таким образом возрастные границы юных исполнителей плавно переходят от младших к старшим, более опытным и искусным и в пении, и в пляске, и в организационных делах во время массовых народных гуляний (Рождество, Масленица, Троица и др.), где старшие «октаевцы» становятся главными заводилами народных праздников.

Хотя по понятным причинам в ансамбле через определенное количество лет происходит ротация (дети-то растут), какое-то количество старших, опытных октаевцев все равно остается в коллективе. На них-то и опирается руководитель, каждый раз начиная все сначала с малышами. Старшие и расскажут, и покажут, и утешат, и помогут, и похвалят. Дужная атмосфера в детском ансамбле, энтузиазм руководителей, привитая с детства и на всю жизнь любовь 


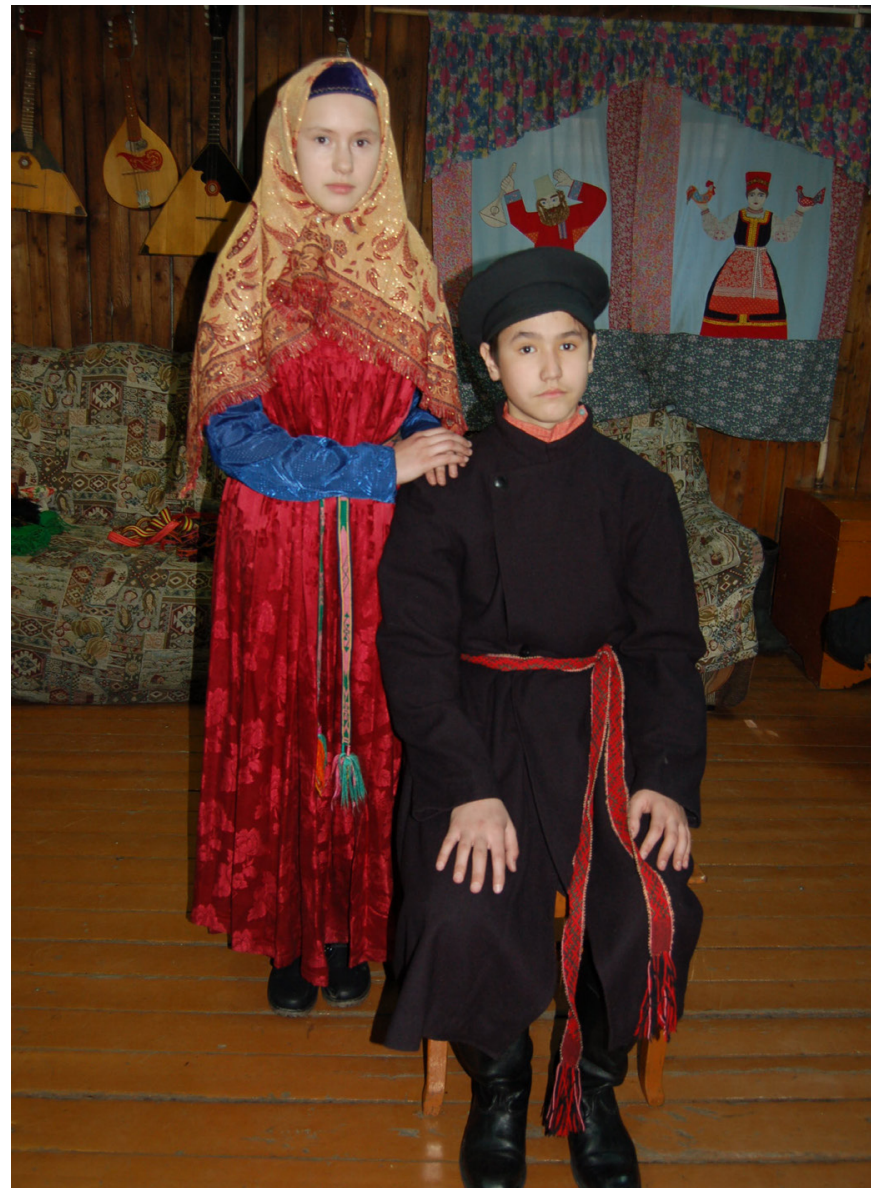

Фото 4. В старообрядческих костюмах. Фото из архива Н. В. Пономаревой. Photo 4. Wearing the traditional Old Believer clothes. Photo from N. V. Ponomaryova's archive.

к народному искусству приводят к тому, что выросшие солисты, «звезды» ансамбля долгое время не порывают с ним связи, выступают в концертах и других представлениях вместе с малышами, участвуют в записях произведений, просто приходят вместе провести все праздники.

Несмотря на самые благоприятные отклики от выступлений ансамбля на самых разных площадках с самым разным репертуаром, наиболее впечатляют отзывы об исполнении «Октаем» духовной музыки, особенно знатоков этого жанра - ученыхэтнографов, музыковедов. Приведу отзыв этнографа Г. В. Любимовой, высказанное автору этих строк: «Что касается “Октая”, то мне доводилось несколько раз слышать этот коллектив (конечно же, не чисто детский!) что называется живьем. Их исполнение духовных стихов поражает и оглушает. Первая мысль, которая приходит в голову - неужели так можно? Ведь они практически еще дети! И тут же понимаешь - да, можно, и это действительно потрясающе! Они, безусловно, уникальные, первые и, по-моему, до сих пор единственные в своем роде». (Надо заметить, что вместе с детьми духовные стихи на концертах обычно поет и руководитель ансамбля Н. В. Пономарева.)

Почти с первых лет существования фольклорного ансамбля проводились летние выезды детей в таежные деревни верховья Малого Енисея на отдых, для знакомства с деревенской жизнью, бытом старообрядцев, в том числе и для записи фольклора, как выяснилось, в основном духовных стихов. Как вспоминает Н. В. Пономарева, исполнители - жители деревень, хорошо знакомые с ансамблем и его руководителями, не слишком возражали во время записи против магнитофона и диктофона, хотя обычно они резко выступают против использования во время записи технических средств (по свидетельству других собирателей-фольклористов и помня собственный опыт). Не допускается техническая запись богослужебных песнопений.

Постепенно стало хорошей традицией выступления детей с концертами перед староверами Эржея и Сизима. Жители сел ждут и любят эти концерты. С учетом состава слушателей соответственно подбирается репертуар - плясовые-частые и развлекательно-игровые песни в этих концертах исполняются реже, предпочтение отдается протяжным русским народным песням, активно исполняются и духовные стихи.

На сегодня репертуар «Октая» включает около 200 духовных стихов, значительная часть из них была записана у местных старообрядцев самими октаевцами, а также фольклористами Г. О. Туденовым, С. Е. Никитиной и автором этой статьи.

Как же руководителям ансамбля удается органично включить эти очень непростые, насыщенные философскими размышлениями, глубоким раскаянием тексты в репертуар детского ансамбля, в котором исполнителям от 6-7 лет до 16-17? Ведь содержание стихов не всегда бы- 
вает понятно даже взрослым, которым многие библейские сюжеты неизвестны, не вполне улавливается и смысл покаянных стихов, часто пронизанных эсхатологическими настроениями.

Однажды в 1996 г. «Октай» принимал участие в работе Всероссийской научной практической конференции «Мир детства и традиционная культура» в Москве - Х Виноградовские чтения, в ее культурной программе (это был самый первый его состав). Там у слушателей возник этот вопрос: понятен ли детям смысл духовных стихов?

Вот как об этом рассказывает Н. В. Пономарева: «Одна ученая дама задала детям вопрос: “Доходит ли до вас смысл, о чем вы поете?” Мой сын (Макар, участник ансамбля. - М. Т.) обиженно на нее посмотрел и спросил: “Зачем вы уж так-то?” Все, кто были в зале, зааплодировали. Мои дети еще долго потом возмущались, что их посчитали недоумками...»

Н. В. Пономарева считает, что дети быстрее и легче усваивают и смысл, и настроение духовных стихов, чем взрослые, хотя, несомненно, для этого необходима определенная подготовка. «В духовных стихах изложено все предельно четко и ясно, - говорит она. - Не могу даже привести пример, где что-то было непонятно для детей. Можно взять любой духовный стих (“Не унывай, душа моя”, “О юности”, “Время радости настало” и т. д.), просто его прочесть и будет все понятно». Предварительная работа с детьми заключается в ознакомлении их с библейскими сюжетами, объяснении их философского смысла, в разъяснении мотивов уныния и скорби в покаянных стихах и т. д. Интересно, что у детей-октаевцев есть любимые духовные стихи: «Стих о юности», «Два ти ангела», «Стих о потопе», «Содом и Гоморра» и др.

Духовные стихи исполняются вместе с псалмами и тропарями (молитвенными песнопениями). Чаще всего они звучат на концертах, приуроченных к великим христианским праздникам (рождественским, пасхальным). В других концертах они занимают места меньше, но

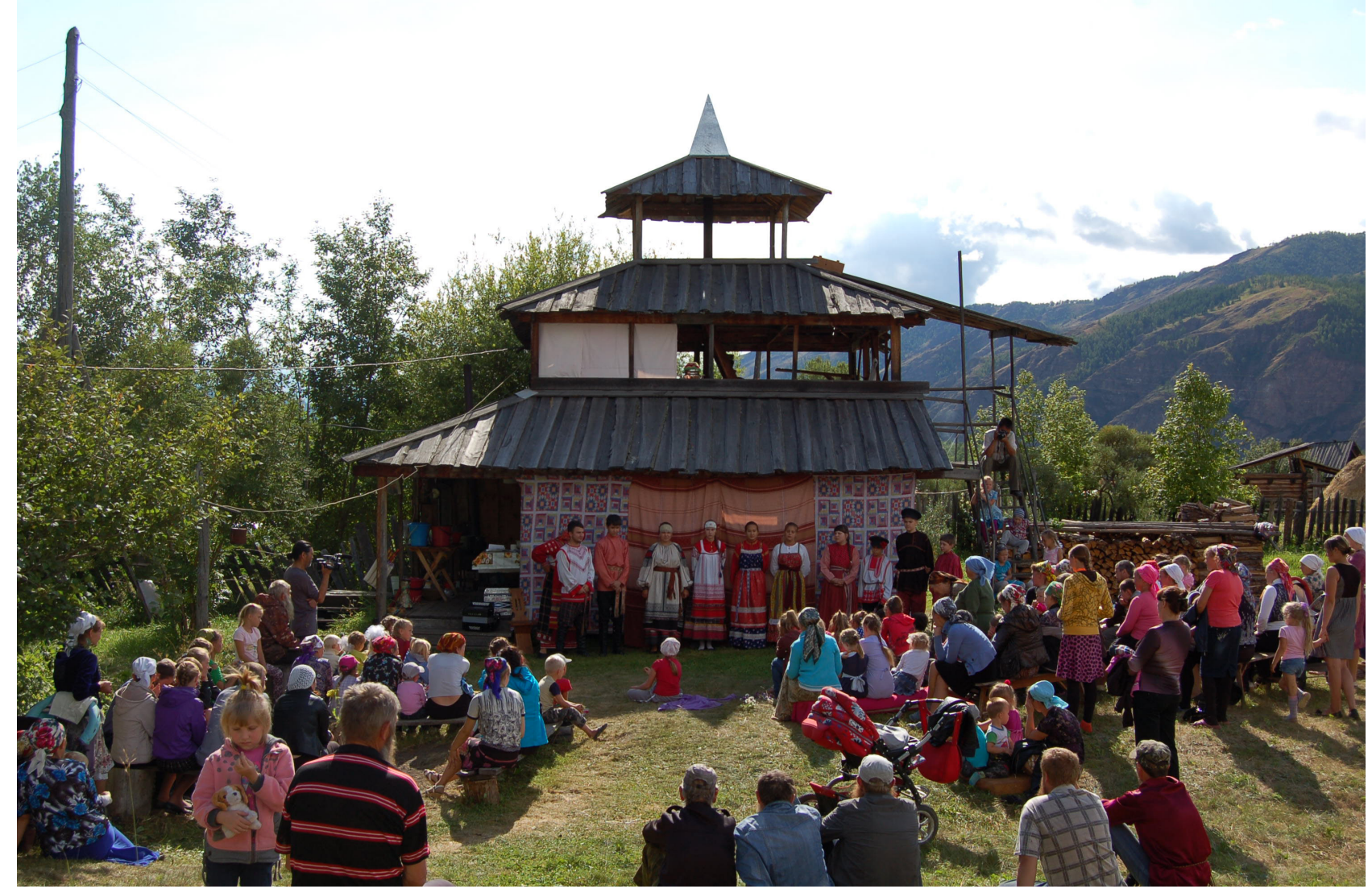

Фото 5. Выступление перед жителями деревни Эржей. Фото из архива Н. В. Пономаревой. Photo 6. A concert for the people of Erzhey village. Photo from N. V. Ponomaryova's archive. 
также исполняются. Здесь надо сказать, что традиция проводить в Кызыле, столице Тувы, народно-церковные календарные праздники - Рождество, Масленица, Пасха, Троица и др. с исполнением календарно-обрядовых песен, с показом традиционных народных игр и забав, фольклорными концертами возродилась во многом благодаря ансамблю «Октай» и с его непременным участием.

Во время выступлений перед жителями с. Эржей слушатели-староверы просят исполнить их любимые духовные стихи, просьбы исполняются непременно.

Должно быть, высокий уровень исполнения детским ансамблем духовных стихов староверов - не самое легкое дело, но тут у руководителя ансамбля свое мнение. Вот как говорит Надежда Васильевна:

«Нам часто задавали вопрос: можно ли детям петь духовные стихи? Время показало: не можно, а нужно! Духовный стих учит не просто слушать и слышать, он учит еще и думать, и сопереживать. Слушая духовные стихи, невольно задумываешься о смысле жизни, в стихах все сказано очень мудро и понятно. Духовные стихи очищают наши души, помогают отрешиться от мирской суеты. В наше время, когда мир захлестывает пошлость и бездуховность, ребенок, увлеченный фольклором, явление очень хрупкое и редкое. Пока дети с чувством и пониманием поют духовные стихи, есть надежда, что не все в нашей культуре потеряно.

Духовные стихи - не для потребителя массовой культуры. У них есть свои слушатели, которым нравится этот жанр. Эти люди выходят на нас и часто предлагают помощь. Например, в издании дисков».

Нельзя сказать, что духовные стихи - самая востребованная у широкой публики часть репертуара ансамбля, к восприятию этого жанра нужна определенная подготовка слушателей. Но у просвещенных слушателей пение детьми библейских, поучительных и покаянных текстов, да еще под аккомпанемент старинного инструмента - колесной лиры, которую многие слушатели-зрители видят впервые, вызывает самое живое, непосредственное сопереживание - от умиления, душевного трепета до воодушевления.

Молодежь староверческих деревень, где постоянно выступает «Октай», по-другому стала относиться к духовным стихам, у некоторых девушек появились современные стихарники тетради или альбомы с записями стихов. С одним из таких «девичьих альбомов» с духовными стихами, принадлежащим жительнице с. Ужеп А. Долговой, автору этих строк довелось познакомиться в начале XXI века. Стихи девушкой записывались в основном обычным почерком, в отдельных случаях - старинным полууставом. Альбом украшали сделанные цветными карандашами или фломастером рисунки - виньетки, изображения птиц, вазонов с цветами и др. Прежде автору этих строк приходилось встречать стихарники у пожилых женщин в виде обычных часто уже потрепанных школьных тетрадок с обычными записями стихов. Н. В. Пономарева сообщила мне также, что бывали случаи, когда молодые староверы просили ее переписать или подарить кассеты иди диски с записями духовных стихов, сделанными ею еще в те времена, когда их родственники были живы.

\section{Заключение}

Исполнение «Октаем» духовных стихов, как мы отметили, производит сильное впечатление особенно на уже «подготовленную» аудиторию, имеющую представление об особенностях этого жанра, традициях его исполнения. Высокие, даже восторженные оценки исполнительскому искусству детского коллектива не раз давались профессионалами-музыковедами, фольклористами. Часто отмечались «высокопрофессиональное исполнение» и «архаическая форма в сочетании с живой традицией», «старообрядческая манера исполнения, очень органичная, напрочь лишенная театральности» и др. Снова приведем суждение музыковеда-профессионала, доктора искусствоведения Е. К. Карелиной: «Уникальность явления под названием “Октай” заключается в том, что его творческая деятельность как бы вливается в местную 
фольклорную традицию, придавая ей новые силы. Происходит своеобразный творческий взаимообмен. Подтверждением этому факту служит пример, когда местные жители Верховья перенимают у “вторичных исполнителей” - “Октая” некоторые не слышанные ими прежде духовные стихи, воспринимая их как свои» (Карелина, 2009: 104).

Опыт ансамбля «Октай», его деятельность по возрождению угасающей традиции пения духовных стихов в среде верхнеенисейских староверов представляет для фольклористов и культурологов, мы считаем, большой интерес. Материальная и духовная культура русского народа стремительно трансформируется и разрушается. Ассимиляция и растворение традиционной культуры в новой культуре - модернизированной, глобализированной и унифицированной, без исторических и национальных корней - невосполнимая утрата для каждого народа. И поэтому деятельность детского ансамбля «Октай», вот уже тридцать лет вносящего свою лепту в дело сохранения традиционной народной культуры, следует всячески поддерживать.

Общественное мнение, сложившееся за тридцатилетнюю историю ансамбля в республике и за ее пределами, таково, что этот уникальный коллектив «сочетает в себе серьезные полевые исследования архаических пластов русской песенной традиции с живыми и разнообразными концертными программами». Руководство республики с гордостью называет «Октай» «визитной карточкой русской культуры в Туве» (Ансамбль ..., 2016: Электр. ресурс), а российская пресса явлением «уникальным», имея в виду нескончаемые творческие поиски и подвижническую деятельность его руководителя.

\section{Благодарности}

Выражаю огромную благодарность руководителю ансамбля «Октай» Надежде Васильевне Пономаревой, благодаря ее стараниям и бесконечному терпению появилась эта статья, сделаны иллюстрации. Моя признательность также близким ей и «Октаю» людям: Ахпашеву Юрию Макаровичу, Вологиной Ирине Васильевне, участникам ансамбля «Верея»- старшим воспитанникам Н. В. Пономаревой, за доброжелательность и желание помочь.

\section{СПИСОК ЛИТЕРАТУРЫ}

Ансамбль «Октай» - визитная карточка Тувы (2016) [Электронный ресурс] // Официальный портал Республики Тыва. 21 января. URL: http://gov.tuva.ru/press_center/news/ society/22299/?sphrase_id=41416 (дата обращения: 12.09.2018).

Карелина, Е. К. (2009) История тувинской музыки от падения династии Цин до наших дней: исследование. М. : Композитор. 552 с.

Костров, А. В., Пригарин, А. А. (2018) Фотография как источник кросскультурного исследования территориальных групп старообрядцев // Традиционная культура. Т. 19. № 2. С. 38-53.

Маслов, П. П. (1933) Конец Урянхая. М. : Молодая гвардия. 144 с.

Никитина, С. Е. (1994а) «Стих надо петь важно и умильно...» // Живая старина. № 3. С. 33-34.

Никитина, С. Е. (1994b) Народная словесность и народное христианство // Живая старина. № 2. С. 11-12.

Покровский, Н. Н. (1984) Путешествие за редкими книгами. М. : Книга. 191 с.

Православный певческий собор (1996) [Электронный ресурс] // Коммерсант. № 74 от 30 апреля. C. 13. URL: https://www.kommersant.ru/doc/132092 (дата обращения: 12.09.2018).

Татаринцева, М. П. (1993) Русские народные песни в Туве. Кызыл : Новости Тувы. 224 с.

Татаринцева, М. П. (2006) Старообрядцы в Туве. Новосибирск : Наука. 216 с.

Татаринцева, М. П. (2017) Фольклор старообрядцев Тувы // Мельниковские чтения / науч. ред. Н. В. Леоновой. Новосибирск : Издательство НГОНБ. 243 с. С. 53-58. 


\section{REFERENCES}

Ansambl' «Oktai» - vizitnaia kartochka Tuvy [Oktai Ensemble - the calling card of Tuva] (2016). Ofitsial'nyi portal Respubliki Tyva, 21 January [online] Available at: http://gov.tuva.ru/press_center/ news/society/22299/?sphrase_id=41416 (access date: 12.09.2018). (In Russ.).

Karelina, E. K. (2009) Istoriia tuvinskoi muzyki ot padeniia dinastii Tsin do nashikh dnei: issledovanie [The history of Tuvan music from the fall of the Qing dynasty to the present day: a study]. Moscow, Kompozitor. 552 p. (In Russ.).

Kostrov, A. V. and Prigarin, A. A. (2018) Fotografiia kak istochnik krosskul'turnogo issledovaniia territorial'nykh grupp staroobriadtsev [Photography as a source of cross-cultural research of territorial groups of Old Believers]. Traditsionnaia kul'tura, vol. 19, no. 2, pp. 38-53. (In Russ.).

Maslov, P. P. (1933) Konets Uriankhaia [The end of Uryankhai]. Moscow, Molodaia gvardiia. 144 p. (In Russ.).

Nikitina, S. E. (1994a) «Stikh nado pet' vazhno i umil'no...» [“The verse is to be sung solemnly and touchingly...”]. Zhivaia starina, no. 3, pp. 33-34. (In Russ.).

Nikitina, S. E. (1994b) Narodnaia slovesnost' i narodnoe khristianstvo [Folk literature and folk Christianity]. Zhivaia starina, no. 2, pp. 11-12. (In Russ.).

Pokrovskii, N. N. (1984) Puteshestvie za redkimi knigami [A journey for rare books]. Moscow, Kniga. 191 p. (In Russ.).

Pravoslavnyi pevcheskii sobor [Orthodox singers convention] (1996). Kommersant, no. 74, 30 April, p. 13 [online] Available at: https://www.kommersant.ru/doc/132092 (access date: 12.09.2018). (In Russ.).

Tatarintseva, M. P. (1993) Russkie narodnye pesni v Tuve [Russian folk songs in Tuva]. Kyzyl, Novosti Tuvy. 224 p. (In Russ.).

Tatarintseva, M. P. (2006) Staroobriadtsy v Tuve [Old Believers in Tuva]. Novosibirsk, Nauka. 216 p. (In Russ.).

Tatarintseva, M. P. (2017) Fol'klor staroobriadtsev Tuvy [The Folklore of Old Believers of Tuva]. In: Mel'nikovskie chteniia [Melnikov readings] / ed. by N. V. Leonova. Novosibirsk, NGONB Publ. 243 p. Pp. 53-58. (In Russ.).

Submission date: 15.10 .2018$. 